\title{
Tomato Breeding Lines Resistant and Tolerant to Tomato Yellow Leaf Curl Virus Issued from Lycopersicon hirsutum
}

\author{
Favi Vidavsky and Henryk Czosnek
}

Department of Field, Vegetable Crops, and Genetics, and the Otto Warburg Center for Biotechnology in Agriculture; Faculty of Agricultural, Food and Environmental Quality Sciences; The Hebrew University of Jerusalem, P.O. Box 12, Rehovot 76100, Israel. Accepted for publication 22 April 1998.

\begin{abstract}
Vidavsky, F., and Czosnek, H. 1998. Tomato breeding lines resistant and tolerant to tomato yellow leaf curl virus issued from Lycopersicon hirsutum. Phytopathology 88:910-914.

Two tomato yellow leaf curl virus (TYLCV)-resistant plants from accessions LA1777 and LA386 of the wild tomato species Lycopersicon hirsutum have been crossed. The resulting resistant F1 plants were crossed with the domesticated tomato L. esculentum, and a series of selfing was performed. At each generation, individuals were selected for resistance (no symptoms and undetectable viral DNA) and tolerance (no symptoms but with detectable viral DNA) following controlled massive and repeated

nated 902) that does not segregate for resistance was obtained. This line does not support virus accumulation, even upon extensive whitefly-mediated inoculation of young seedlings, and does not need protection with nets or insecticides. Another stable BC1F4 line (denominated 908) was tolerant to the virus. Both lines have good horticultural characteristics and bear $80-$ to $120-\mathrm{g}$ red fruits. Analysis of segregation of susceptibility, tolerance, and resistance during the $\mathrm{BC} 1 \mathrm{~F} 1$ to $\mathrm{BC} 1 \mathrm{~F} 4$ crosses indicated that tolerance is controlled by a dominant major gene and resistance by two to three additive recessive genes. The resistant and tolerant lines do not need to be protected by insecticides or nets.
\end{abstract} inoculations with viruliferous whiteflies. A stable BC1F4 line (denomi-
Additional keywords: Bemisia tabaci, disease resistance, Lycopersicon spp.
Tomato yellow leaf curl virus (TYLCV) is the name given to a group of geminiviruses transmitted by the whitefly Bemisia tabaci (synonym $B$. argentifolii) (4-6). TYLCV infects tomatoes in open fields and greenhouses, causing up to $100 \%$ losses in crop production in many countries in the Middle East, southwest Europe, tropical Africa, southeast Asia, and the Caribbean Islands (7). The cloned TYLCV isolates from Israel and from the Mediterranean basin possess a single genomic molecule (7).

Breeding programs aimed at producing tomato cultivars resistant to TYLCV started in the late 1960s and have expanded since. These programs are based on the introgression of resistance or tolerance found in some accessions of wild tomato species into the domesticated tomato Lycopersicon esculentum. Depending on the plant source, resistance was reported to be controlled by one to five genes, either recessive or dominant $(17,21)$. The first commercial tolerant cultivar, TY20, carrying tolerance from $L$. peruvianum (18) showed delayed symptoms and accumulation of viral DNA (19). A TYLCV-tolerant gene originating from L. chilense LA1969, Ty-1, has been mapped to tomato chromosome 6 using restriction fragment length polymorphism markers and has been introgressed into L. esculentum $(13,22)$. Another tolerant gene originating from $L$. pimpinellifolium has been mapped using random amplified polymorphic DNA markers, also to chromosome 6 but to a locus different from $T y-1$ (2).

After more than 25 years of effort, the best cultivars and breeding lines available show tolerance to the virus rather than resistance (17). Upon infection, yields are far higher than those of susceptible cultivars and disease symptoms are absent or very mild, but all contain various amounts of virus (12). Moreover, these tolerant cultivars need to be protected from viruliferous insects with insecticides or nets during the first month after planting. Hence,

Corresponding author: H. Czosnek; E-mail address: czosnek@agri.huji.ac.il

Publication no. P-1998-0702-01R

(c) 1998 The American Phytopathological Society we have initiated a breeding program with the ultimate goal of obtaining cultivars totally resistant to whitefly-mediated inoculation and that do not allow virus accumulation, thereby rendering superfluous the use of insecticides or nets.

\section{MATERIALS AND METHODS}

Plants and virus and insect cultures. Twenty-day-old seedlings of wild and domesticated tomato, grown in a nursery, were planted in 0.5 -liter pots and kept in an insect-proof nethouse. $B$. tabaci of the B biotype (3) were maintained on eggplants (Solanum melongena cv. Classic) and on cotton (Gossypium hirsutum cv. Akkala) in insect-proof cages held at $26^{\circ} \mathrm{C}$ in an insect-proof growth chamber. Virus isolates were maintained in tomato plants (L. esculentum cv. Daniela) and propagated by whitefly-mediated transmission.

Whitefly-mediated inoculation. Insects that acquired TYLCV during a 48-h acquisition feeding on infected tomato plants were used for inoculation. An inoculation routine was used to avoid escape (20). Twenty-day-old seedlings were inoculated in the greenhouse by caging viruliferous whiteflies for 5 days, 10 to 20 insects per plant. Fourteen days thereafter, the plants were tested for the presence of viral DNA by squash blot hybridization (described below). Plants without detectable viral DNA were individually caged with 20 to 40 viruliferous insects for an additional 48-h inoculation period. All plants were then planted in an infested field. The presence of viral DNA was assayed up to 130 days later, using squashes of two to four apices for each plant. Symptoms were monitored for this entire period.

Detection of TYLCV DNA. Approximately $1 \mathrm{~cm}^{2}$ of tissue from the shoot apex was squashed on a nylon membrane (Hybond N; Amersham Corp., Arlington Heights, IL) and hybridized (14) with the radiolabeled plasmid pTYH20.7 bearing tandemly repeated copies of the cloned genome of a TYLCV isolate from Israel (15). Viral DNA was also detected by Southern blot analysis (1) and by polymerase chain reaction (PCR) (16). 
Embryo culture. F1 seeds resulting from a cross between the L. hirsutum hybrid LA1777 $\times$ LA386 and L. esculentum were sterilized for $15 \mathrm{~min}$ in $3 \%$ commercial bleach and rinsed three times in sterile water. A small cut was made alongside the embryo. The cut side of the seeds were placed in a petri dish on a solid medium containing MS salt mixture (Gibco Ltd., Paisley, Scotland), $100 \mathrm{mg}$ of myoinositol per liter, $0.4 \mathrm{mg}$ of thiamine$\mathrm{HCl}$ per liter, $30 \mathrm{~g}$ of sucrose per liter, and $8 \mathrm{~g}$ of Bacto agar per liter, $\mathrm{pH}$ 5.8. The seeds were incubated at $25^{\circ} \mathrm{C}$ under cool white fluorescent lights (16-h light/8-h dark). Seeds that germinated were transplanted individually into tubes containing $10 \mathrm{ml}$ of the medium described above. The seedlings were transferred to soil when they reached 2 to $4 \mathrm{~cm}$ in height. After a period of acclimatization, the plants were transferred to the greenhouse.

\section{RESULTS}

Accessions of wild Lycopersicon species contained individuals susceptible, tolerant, and resistant to TYLCV. Plants from seven accessions of wild tomato species (Table 1) listed as tolerant or resistant to TYLCV $(17,21)$ were tested for their response to whitefly-mediated inoculation. TYLCV DNA and symptoms were monitored for up to 4 months after inoculation. Plants exhibiting symptoms and containing viral DNA were classified as susceptible, symptomless plants that contained viral DNA were classified as tolerant, and symptomless plants without detectable viral DNA (by hybridization and by PCR) were considered as resistant. The results summarized in Table 1 show that, within each of the accessions tested, the response of individual plants to inoculation varied from susceptibility to resistance. Susceptible, tolerant, and resistant plants were found in accession LA1582 of L. pimpinellifolium. Only susceptible and tolerant individuals were found in accession LA121 of L. pimpinellifolium. Accessions LA372 and LA462 of L. peruvianum, LA1777 of L. hirsutum, and LA1969 of L. chilense contained tolerant and resistant individuals. The two L. hirsutum accessions comprised the highest proportion of resistant individuals.

Hybrids resulting from a cross between $L$. hirsutum accessions LA1777 and LA386 were resistant. Plants from the two $L$. hirsutum accessions LA1777 and LA386 were crossed. Plants from $L$. hirsutum accessions were also crossed with the susceptible $L$. esculentum (the wild species were used as the male parent). The F1 plants were inoculated with viruliferous whiteflies; symptoms and viral DNA were monitored thereafter. The results summarized in Table 2 indicate that all the plants resulting from the cross

TABLE 1. Response of selected accessions of Lycopersicon species (wild tomato) 4 months after inoculation

\begin{tabular}{lccccc}
\hline \multirow{2}{*}{ Wild tomato species } & \multirow{2}{*}{$\begin{array}{c}\text { Accession } \\
\text { number }\end{array}$} & $\begin{array}{c}\text { Number } \\
\text { of plants }\end{array}$ & \multicolumn{2}{c}{ Response to inoculation } \\
\cline { 5 - 7 } L. pimpinellifolium & LA121 & 10 & 7 & 3 & 0 \\
& LA1582 & 16 & 9 & 4 & 3 \\
L. peruvianum & LA372 & 8 & 0 & 2 & 6 \\
\multirow{2}{*}{ L. hirsutum } & LA462 & 9 & 0 & 5 & 4 \\
& LA1777 & 16 & 0 & 1 & 15 \\
L. chilense & LA386 & 10 & 0 & 0 & 10 \\
\hline
\end{tabular}

a Viral DNA appeared 50 days after inoculation.

TABLE 2. Response of F1 hybrids between susceptible Lycopersicon esculentum and resistant $L$. hirsutum plants, and of $\mathrm{F} 1$ hybrids between resistant plants of two L. hirsutum accessions 4 months after inoculation

\begin{tabular}{lccccc}
\hline & \multirow{2}{*}{ Parents } & & \multicolumn{3}{c}{ Response of F1 to inoculation } \\
\cline { 1 - 1 } \cline { 5 - 7 } Male & \multicolumn{1}{c}{ Female } & tested & Susceptible & Tolerant & Resistant \\
\hline LA1777 & L. esculentum & 10 & 8 & 2 & 0 \\
LA386 & L. esculentum & 6 & 6 & 0 & 0 \\
LA386 & LA1777 & 9 & 0 & 0 & 9 \\
\hline
\end{tabular}

between the two L. hirsutum accessions were resistant to TYLCV inoculation. The cross LA1777 $\times$ L. esculentum gave susceptible and tolerant plants, while the cross LA386 $\times$ L. esculentum gave susceptible plants only. These results provided the first indication that the genes controlling resistance are recessive and the genes controlling tolerance are partly or completely dominant.

F1 plants resulting from a cross between the resistant hybrid LA1777 $\times$ LA386 and L. esculentum were tolerant. Tolerance and resistance were introgressed into the domesticated tomato $L$. esculentum according to the flow chart described in Figure 1. Since L. hirsutum LA1777 and LA386 are self-incompatible, the cross among them did not bear fruits. Therefore, pollen was collected from two resistant hybrid plants LA1777 × LA386 (denominated hir-5 and hir-7, respectively) and was used to pollinate $L$. esculentum. Because of lack of germination, embryo culture was used to obtain germinating seeds. The resulting F1 plants were challenged with viruliferous whiteflies. The F1 plants that originated from the hir-5 plant were susceptible and those originated from the hir-7 plant were tolerant to TYLCV. The tolerant F1 that originated from hir-7 was used for further introgression into the domesticated tomato. Because the F1 plants did not bear fruits, their pollen was again used to pollinate L. esculentum. Ten BC1F1 plants were obtained that produced red fruits. Upon whiteflymediated inoculation, tolerant and susceptible BC1F1 individuals (but no resistant) were obtained in a ratio of 1:1.

Progeny of a tolerant BC1F1 plant segregated for susceptibility, tolerance, and resistance. One tolerant $\mathrm{BC} 1 \mathrm{~F} 1$ plant was selfed. Sixty BC1F2 progeny were inoculated with viruliferous whiteflies. Appearance of symptoms and of DNA (by squash blot hybridization) (Fig. 2) was monitored thereafter. Results are summarized in Table 3. Twenty-two days after inoculation, seven plants did not show detectable amounts of viral DNA (Fig. 2A). This number decreased to four 16 days later (Fig. 2B). Seventy-two days

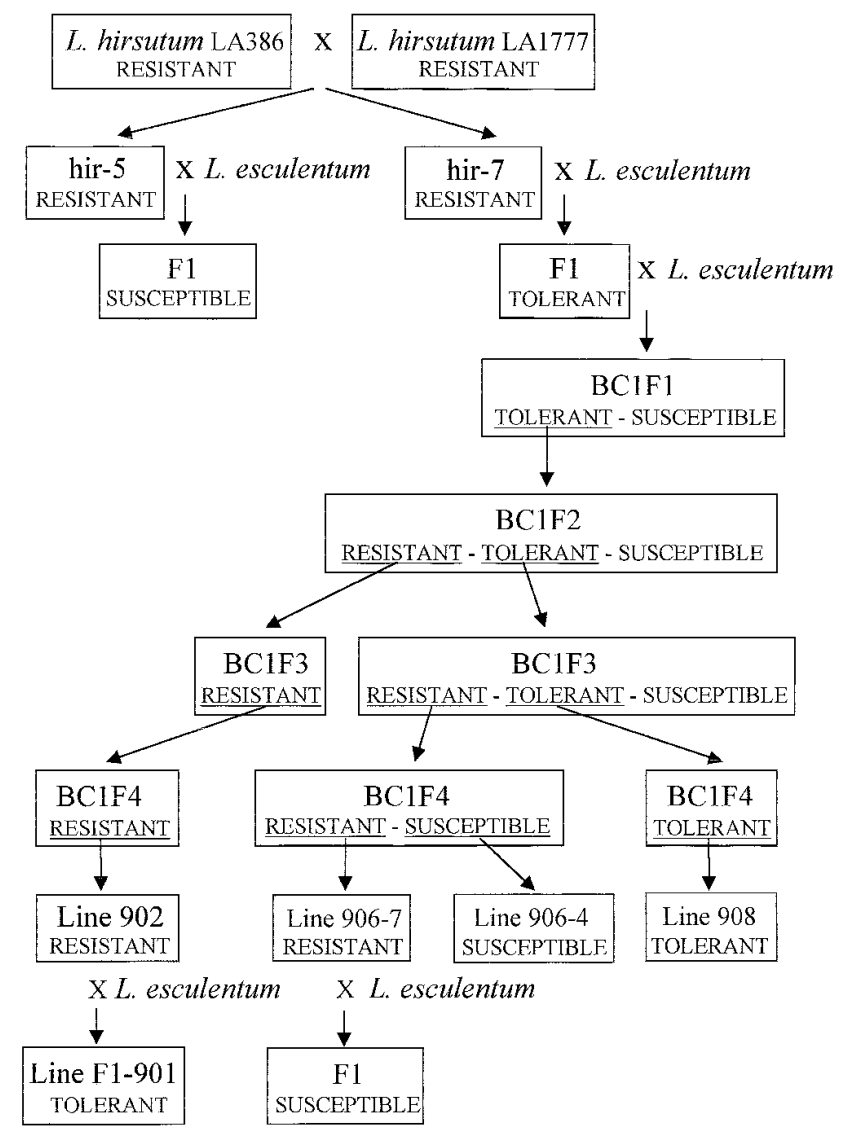

Fig. 1. Flow chart of crosses for the production of tomato lines issued from Lycopersicon hirsutum. 
after inoculation, squash blot hybridization (Fig. 2C) and the appearance of symptoms indicated that 19 plants were susceptible and 39 were tolerant. Viral DNA was undetectable in two symptomless plants (numbers 25 and 59) (Fig. 2C). Only one plant (number 25) (Fig. 2D) did not contain detectable viral DNA 134 days after inoculation (and 30 days after reinoculation); the second plant (number 59) (Fig. 2D) showed traces of viral DNA. Plant 25 was multiplied by cuttings and was reinoculated with viruliferous insects. Neither symptoms nor DNA were detected in these plants. Attempts to amplify viral DNA from the shoot apex, stem, or older leaves (2 months after reinoculation of cuttings) by PCR remained unsuccessful (data not shown). To ensure that plant number 25 did not contain virus, shoots from this plant were grafted with uninfected L. esculentum; no viral DNA was detected and no symptoms were observed in the susceptible plant 30 days after grafting (data not shown). TYLCV DNA was undetectable in plant number 25. In the $\mathrm{BC} 1 \mathrm{~F} 2$ population, segregation between susceptible and tolerant plants indicates that a single dominant gene controls tolerance. Segregation between resistant plants and all the others (susceptible and tolerant) suggests that two to three additive recessive genes control resistance.

Grafting experiments were conducted to understand the basis of the difference between tolerance and resistance. Cuttings from tolerant $\mathrm{BC} 1 \mathrm{~F} 2$ plant number 21 and resistant $\mathrm{BC} 1 \mathrm{~F} 2$ plant number 25 were grafted with susceptible plants 30 days after inoculation as scion or as understock. DNA and symptoms were monitored every week following grafting; the results are summarized in Table 4. When both segments of the graft are susceptible, TYLCV can move from the understock to the scion and vice versa, and the graft is symptomatic (Table 4, plants A and B). In the case in which the virus source is in the infected susceptible scion or understock, it invaded the tissues of the resistant (Table 4, plants $\mathrm{C}$

\section{Squash Hybridization}

Squash Hybridization
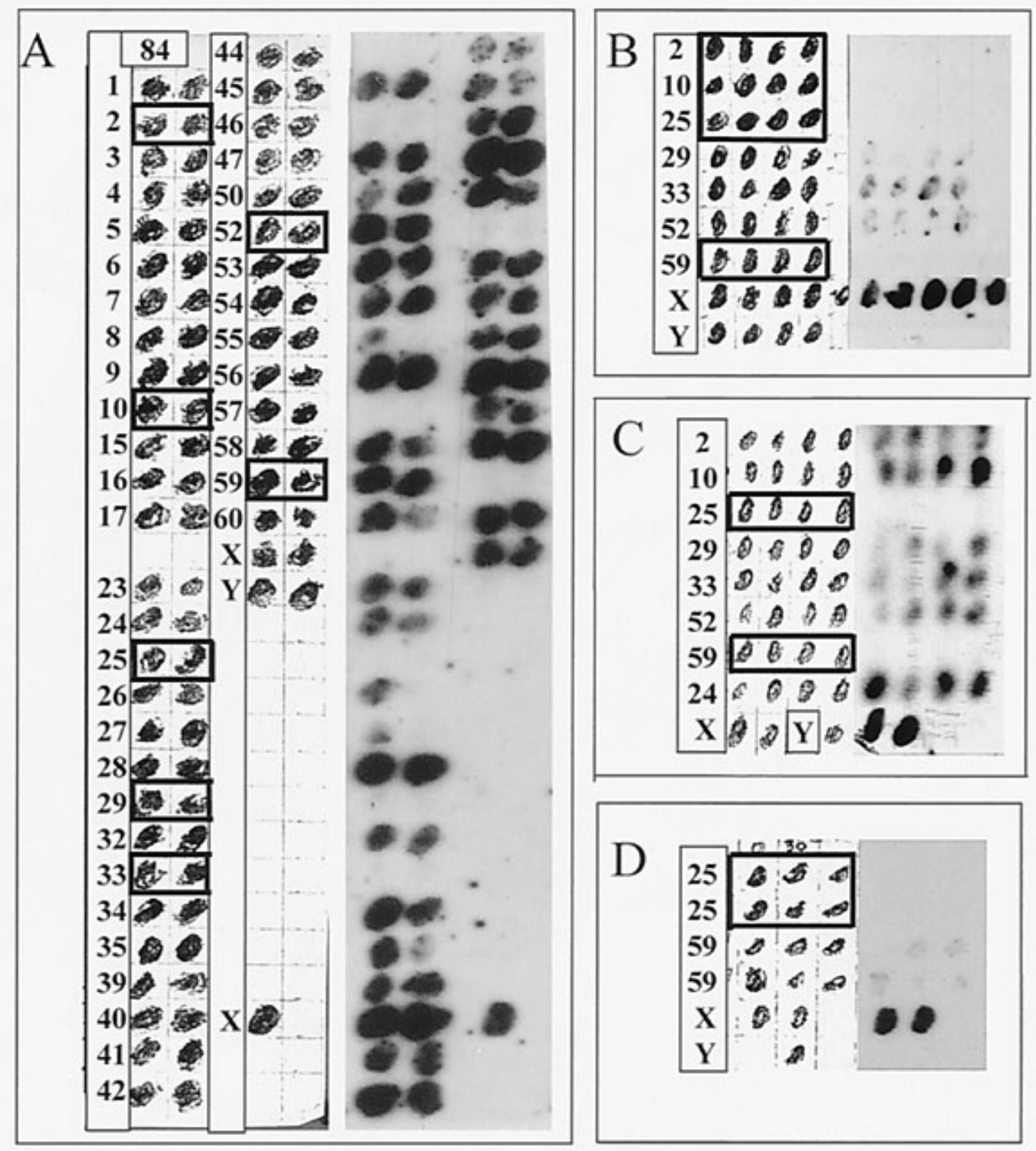

Fig. 2. Squash blot hybridization of young leaves of BC1F2 tomato plants following inoculation with viruliferous whiteflies. X: infected susceptible plants; Y: noninfected plants. A, Plant numbers 1 to 60, 22 days after inoculation (two samples per plant). B, Plant numbers 2, 10, 25, 29, 33, and 59, 38 days after inoculation (four samples per plant). C, Plant numbers 2, 10, 25, and 59, 72 days after inoculation (four samples per plant). D, Plant numbers 25 and 59, 134 days after inoculation (six samples per plant). Plants with no detectable viral DNA are boxed. 
and D) and the tolerant (Table 4, plants E and F) plant, but did not produce symptoms in any of them. Therefore, resistance, but not tolerance, is lost once the virus is present in the vascular system.

The progeny of the resistant $\mathrm{BC} 1 \mathrm{~F} 2$ plant were resistant. All $\mathrm{BC} 1 \mathrm{~F} 2$ plants were selfed and seeds were collected. Forty-five of the sixty $\mathrm{BC} 1 \mathrm{~F} 2$ plants produced progeny. Five to eight $\mathrm{BC} 1 \mathrm{~F} 3$ plants, progeny of each $\mathrm{BC} 1 \mathrm{~F} 2$ plant, were inoculated with viruliferous whiteflies. The results summarized in Table 3 show that all progeny of susceptible $\mathrm{BC} 1 \mathrm{~F} 2$ plants were susceptible, except for the progeny of plant number 33, which comprised a resistant individual. The progeny of tolerant $\mathrm{BC} 1 \mathrm{~F} 2$ plants divided into two groups. In the first group, all plants were tolerant (e.g., progeny of plant numbers 2 and 4). In the second group, plants segregated (in variable ratio) to susceptibility, tolerance, and resistance (e.g., progeny of plant numbers 10 and 26); to susceptibility and tolerance (e.g., progeny of plant numbers 3 and 11); or to tolerance and resistance (e.g., progeny of plant numbers 45 and 50). None of the tolerant $\mathrm{BC} 1 \mathrm{~F} 2$ plants produced progeny with only susceptible and resistant plants. The progeny of the resistant $\mathrm{BC} 1 \mathrm{~F} 2$ plant number 25 did not segregate; all $\mathrm{BC} 1 \mathrm{~F} 3$ plants were resistant. The progeny of $\mathrm{BC} 1 \mathrm{~F} 2$ plant number 59 , which showed traces of viral DNA more than 3 months after inoculation (Fig. 1), included resistant and tolerant plants. The $\mathrm{BC} 1 \mathrm{~F} 3$ segregation confirmed that one dominant major gene controls tolerance, and two to three recessive additive genes control resistance.

Stabilization of $\mathrm{BC1F} 4$ plants for tolerance and resistance. To stabilize the tolerant and resistant traits, $\mathrm{BC} 1 \mathrm{~F} 4$ populations were obtained. The resistant plants $\mathrm{BC} 1 \mathrm{~F} 3$ issued from the resistant BC1F2 plant number 25 were selfed. All BC1F4 plants were resistant to whitefly-mediated inoculation. Several plants with good horticultural qualities were chosen for further breeding. Subsequent selfing showed that this line (denominated 902) was stable and remained resistant to TYLCV. Plants had L. esculentum plant

TABLE 3. Response of progeny of susceptible (S), tolerant (T), and resistant (R) BC1F2 plants to inoculation

\begin{tabular}{|c|c|c|c|c|c|}
\hline \multicolumn{2}{|c|}{$\mathrm{BC} 1 \mathrm{~F} 2$} & \multirow{2}{*}{$\frac{\text { BC1F3 }}{\text { Segregation } \mathrm{S}-\mathrm{T}-\mathrm{R}^{\mathrm{a}}}$} & \multicolumn{2}{|c|}{ BC1F2 } & \multirow{2}{*}{$\frac{\text { BC1F3 }}{\text { Segregation S-T-R }}$} \\
\hline No. & Status & & No. & Status & \\
\hline 1 & $\mathrm{~T}$ & n.g. ${ }^{b}$ & 31 & $\mathrm{~T}$ & $0-8-0$ \\
\hline 2 & $\mathrm{~T}$ & $0-6-0$ & 32 & $\mathrm{~S}$ & n.g. \\
\hline 3 & $\mathrm{~T}$ & $1-7-0$ & 33 & $\mathrm{~S}$ & $7-0-1$ \\
\hline 4 & $\mathrm{~T}$ & $0-8-0$ & 34 & $\mathrm{~S}$ & n.g. \\
\hline 5 & $\mathrm{~T}$ & n.g. & 35 & $\mathrm{~T}$ & $0-5-0$ \\
\hline 6 & $\mathrm{~S}$ & n.g. & 36 & $\mathrm{~T}$ & $1-7-0$ \\
\hline 7 & $S$ & n.g. & 37 & $\mathrm{~T}$ & $2-6-0$ \\
\hline 8 & $\mathrm{~T}$ & $0-7-0$ & 38 & $\mathrm{~T}$ & $0-7-0$ \\
\hline 9 & $\mathrm{~T}$ & $0-8-0$ & 39 & $\mathrm{~T}$ & $0-5-0$ \\
\hline 10 & $\mathrm{~T}$ & $3-3-2$ & 40 & $S$ & $8-0-0$ \\
\hline 11 & $\mathrm{~T}$ & $1-5-0$ & 41 & $\mathrm{~T}$ & $0-7-0$ \\
\hline 12 & $\mathrm{~S}$ & $6-0-0$ & 42 & $\mathrm{~T}$ & $0-5-0$ \\
\hline 13 & $\mathrm{~T}$ & $1-5-0$ & 43 & $\mathrm{~T}$ & $0-5-0$ \\
\hline 14 & $\mathrm{~T}$ & $2-6-0$ & 44 & $\mathrm{~S}$ & n.g. \\
\hline 15 & $\mathrm{~S}$ & n.g. & 45 & $\mathrm{~T}$ & $0-6-1$ \\
\hline 16 & $\mathrm{~T}$ & $0-6-0$ & 46 & $\mathrm{~T}$ & $0-8-0$ \\
\hline 17 & $\mathrm{~S}$ & $7-0-0$ & 47 & $\mathrm{~S}$ & $3-0-0$ \\
\hline 18 & $\mathrm{~T}$ & n.g. & 48 & $\mathrm{~T}$ & $0-8-0$ \\
\hline 19 & $\mathrm{~S}$ & $8-0-0$ & 49 & $\mathrm{~T}$ & $3-3-0$ \\
\hline 20 & $\mathrm{~S}$ & $8-0-0$ & 50 & $\mathrm{~T}$ & $0-6-1$ \\
\hline 21 & $\mathrm{~T}$ & $0-8-0$ & 51 & $\mathrm{~T}$ & $5-3-0$ \\
\hline 22 & $\mathrm{~T}$ & $1-7-0$ & 52 & $\mathrm{~T}$ & n.g. \\
\hline 23 & $\mathrm{~S}$ & n.g. & 53 & $\mathrm{~T}$ & $0-6-2$ \\
\hline 24 & $\mathrm{~S}$ & $8-0-0$ & 54 & $\mathrm{~T}$ & $0-8-0$ \\
\hline 25 & $\mathrm{R}$ & $0-0-8$ & 55 & $\mathrm{~T}$ & $0-6-1$ \\
\hline 26 & $\mathrm{~T}$ & $3-4-1$ & 56 & $\mathrm{~S}$ & n.g. \\
\hline 27 & $\mathrm{~T}$ & n.g. & 57 & $\mathrm{~S}$ & n.g. \\
\hline 28 & $\mathrm{~S}$ & $2-0-0$ & 58 & $\mathrm{~S}$ & $3-0-0$ \\
\hline 29 & $\mathrm{~T}$ & $2-6-0$ & 59 & $\mathrm{R}$ & $0-6-2$ \\
\hline 30 & $\mathrm{~T}$ & n.g. & 60 & $\mathrm{~T}$ & $0-3-0$ \\
\hline
\end{tabular}

a $\mathrm{S}-\mathrm{T}-\mathrm{R}=$ number of $\mathrm{BC} 1 \mathrm{~F} 3$ plants segregating to susceptibility, tolerance, and resistance. Estimated 4 months after inoculation.

${ }^{\mathrm{b}}$ n.g. = not germinated . morphologies, were self-compatible, and produced red fruits weighing between 80 and $120 \mathrm{~g}$.

The resistant $\mathrm{BC} 1 \mathrm{~F} 3$ plant issued from the tolerant $\mathrm{BC} 1 \mathrm{~F} 2$ plant number 10 was selfed. The BC1F4 progeny included plants that were either resistant or susceptible to whitefly-mediated inoculation; further selfing of the resistant or susceptible plants produced only resistant (line 906-7) or susceptible (line 906-4) plants. The tolerant $\mathrm{BC} 1 \mathrm{~F} 3$ plants issued from the tolerant $\mathrm{BC} 1 \mathrm{~F} 2$ plant number 10 were selfed. The $\mathrm{BC} 1 \mathrm{~F} 4$ progeny plants were all tolerant to whitefly-mediated inoculation. Subsequent selfing showed that this line (denominated 908) was stable and remained tolerant to TYLCV. All these lines had L. esculentum characteristics and produced red fruits weighing between 80 and $120 \mathrm{~g}$.

Production of F1 hybrids between resistant lines and $L$. esculentum. Plants of the resistant lines 902 and 906-7 and of the susceptible line 906-4 were crossed with L. esculentum. The results presented in Table 5 indicated that all F1 plants issued from the susceptible line 906-4 and from the resistant line 906-7 were susceptible. All F1 plants issued from the resistant line 902 were tolerant. These data indicate that resistance and tolerance are under the control of different gene systems.

The fruits of line F1-901, the F1 between the resistant line 902 and $L$. esculentum, had weights of 120 to $150 \mathrm{~g}$. The plants had $L$. esculentum morphological characteristics and an excellent fruit set. All tolerant and resistant lines can be planted in infested fields and do not need protection of insecticides or insect-proof nets.

\section{DISCUSSION}

Before TYLCV-DNA probes became available, selection for TYLCV resistance was based on the absence (or attenuation) of symptoms in infested fields and in amelioration of yields. Today, we realize that all tomato cultivars and lines currently available are, at best, tolerant to TYLCV; although yields and symptoms have much improved compared with susceptible cultivars, plants contain various concentrations of virus (12). To the best of our knowledge, none of the tomato cultivars are resistant (no symptoms, no virus). The only wild tomato species reported to be resistant upon whitefly-mediated inoculation was L. chilense LA1969 (21). Mapping and introgression of resistance from $L$. chilense has led to a tolerant line, in which virus replication and movement is slower than in the susceptible near-isogenic line (13). We have initiated a breeding program with the ultimate goal of obtaining cultivars totally resistant to whitefly-mediated inoculation. Screening of accessions of wild tomato species reported to be resistant to TYLCV has shown that susceptible, tolerant, and resistant individuals can be found within each accession. This heterogeneity is

TABLE 4. Response of resistant and tolerant tomato 3 months after grafting with inoculated susceptible tissues

\begin{tabular}{|c|c|c|c|c|c|c|}
\hline \multirow[b]{2}{*}{ Plant } & \multicolumn{2}{|c|}{ Understock } & \multicolumn{2}{|c|}{ Scion } & \multicolumn{2}{|c|}{ Result } \\
\hline & Status & Infected & Status & Infected & Viral DNA & Symptoms \\
\hline A & Susceptible & No & Susceptible & Yes & Yes & Yes \\
\hline B & Susceptible & Yes & Susceptible & No & Yes & Yes \\
\hline $\mathrm{C}$ & Susceptible & Yes & Resistant & No & Yes & No \\
\hline D & Resistant & No & Susceptible & Yes & Yes & No \\
\hline E & Susceptible & Yes & Tolerant & No & Yes & No \\
\hline $\mathrm{F}$ & Tolerant & No & Susceptible & Yes & Yes & No \\
\hline
\end{tabular}

TABLE 5. Response of F1 hybrids between resistant lines and susceptible Lycopersicon esculentum 4 months after inoculation

\begin{tabular}{lllccc}
\hline \multicolumn{1}{c}{ Parents } & & \multicolumn{3}{c}{ F1 hybrid (10 plants) } \\
\cline { 1 - 2 } \cline { 5 - 6 } Male & Female & & Susceptible & Tolerant & Resistant \\
\hline H-906-4 (susceptible) & L. esculentum & & 10 & 0 & 0 \\
H-906-7 (resistant) & L. esculentum & & 10 & 0 & 0 \\
H-902 (resistant + tolerant) & L. esculentum & 0 & 10 & 0 \\
\hline
\end{tabular}


probably due to the fact that most wild species in their propagation routine are subject to open pollination, especially if they have self-incompatibility genes like in L. hirsutum, L. chilense, and $L$. peruvianum.

We started our breeding program with a cross between plants from L. hirsutum accessions LA1777 and LA386 completely resistant to TYLCV. L. hirsutum LA386 was reported to be resistant to TYLCV from Jordan; several dominant genes controlled the resistance (9). L. hirsutum LA1777 was reported to be resistant to TYLCV from Cyprus (10) and tolerant to TYLCV from Sardinia and from Senegal and to tomato leaf curl virus from India (8). The L. hirsutum F1 (LA1777 $\times$ LA386) was crossed with L. esculentum, and a series of selfing were performed. At each generation, individuals were selected for resistance following repeated, massive, controlled inoculations with viruliferous whiteflies. Segregation of progeny for resistance, tolerance, and susceptibility indicated that resistance and tolerance are controlled by different sets of genes. Segregation in the BC1F3 population supports a model in which resistance is controlled by two to three additive recessive genes. In a given plant, tolerance can be masked by resistance. These two traits may separate after selfing and segregate at the next generation. Grafting can also separate resistance and tolerance. For example, plant number 25 (Table 3) remained symptomless when grafted on a susceptible infected plant (Table 4, plants $C$ and D), because it carries a gene for tolerance that is masked by the genes conferring resistance. Contrary to resistance, tolerance is controlled by one dominant major gene. The recessive nature of resistance and the fact that it is a polygenic trait may explain the difficulties in introgressing this trait into the domesticated tomato. Grafting experiments have shown that resistance is lost when an infected susceptible plant is grafted with a resistant plant (as scion or not): the resistant plant becomes tolerant. Therefore, we suggest that resistance is expressed at the whitefly-plant interface. Once the virus is in the vascular system, resistance is lost. Similar results were reported showing a break of resistance of L. chilense LA1969 and of L. hirsutum LA1777 following TYLCV delivery by agroinoculation (11).

We have now reached a stable BC1F4 line (denominated 902) that does not segregate for resistance and that has good horticultural characteristics (80- to 120 -g red fruits, fertility, self-compatibility, vigor, and good plant morphology). This line does not support virus replication even upon controlled massive whitefly-mediated inoculation of young seedlings and does not need protection with nets or insecticides. The F1 with L. esculentum is tolerant, produces 120 - to $150-\mathrm{g}$ fruits, and does not need protection from inoculation.

\section{ACKNOWLEDGMENTS}

Supported by the chief scientist of the Ministry of Agriculture, Israel, grant 811-0184-95; by the U.S. Agency for International Development, grant TA-MOU-96-C16-020; and by the United States-Israel Binational Agricultural Research and Development Fund project IS-2566-95R.

\section{LITERATURE CITED}

1. Ber, R., Navot, N., Zamir, D., Antignus, Y., Cohen, S., and Czosnek, H. 1990. Infection of tomato by the tomato yellow leaf curl virus: Susceptibility to infection, symptom development and accumulation of viral DNA. Arch. Virol. 112:169-180.
2. Chague, V., Mercier, J. C., Guenard, M., de Courcel, A., and Vedel, F. 1997. Identification of RAPD markers linked to a locus involved in quantitative resistance to TYLCV in tomato by bulked segregant analysis. Theor. Appl. Genet. 95:671-677.

3. Cohen, S. 1993. Sweet potato whitefly biotypes and their connection with squash silver leaf. Phytoparasitica 21:174

4. Cohen, S., and Harpaz, I. 1964. Periodic, rather than continual acquisition of a new tomato virus by its vector, the tobacco whitefly (Bemisia tabaci Gennadus). Entomol. Exp. Appl. 7:155-166.

5. Cohen, S., and Nitzany, F. E. 1966. Transmission and host range of the tomato yellow leaf curl virus. Phytopathology 56:1127-1131.

6. Czosnek, H., Ber, R., Antignus, Y., Cohen, S., Navot, N., and Zamir, D. 1988. Isolation of tomato yellow leaf curl virus, a geminivirus. Phytopathology 78:508-512.

7. Czosnek, H., and Laterrot, H. 1997. A worldwide survey of tomato yellow leaf curl viruses. Arch. Virol. 142:1391-1406.

8. Fargette, D., Leslie, M., and Harrison, B. D. 1996. Serological studies on the accumulation and localisation of three tomato leaf curl geminiviruses in resistant and susceptible Lycopersicon species and tomato cultivars. Ann. Appl. Biol. 128:317-328.

9. Hassan, A. A., Mazayad, H. M., Moustafa, S. E., Nassar, S. H., Nakhla, M. K., and Sims, W. L. 1984. Inheritence of resistance to tomato yellow leaf curl virus derived from Lycopersicon cheesmanii and Lycopersicon hirsutum. HortScience 19:574-575.

10. Ioannou, N. 1985. Yellow leaf curl and other diseases of tomato in Cyprus. Plant Pathol. 345:428-434.

11. Kheyr-Pour, A., Gronenborn, B., and Czosnek, H. 1994. Agroinoculation of tomato yellow leaf curl virus (TYLCV) overcomes the virus resistance of wild Lycopersicon species. Plant Breed. 112:228-233.

12. Lapidot, M., Friedmann, M., Lachman, O., Yehezkel, A., Nahon, S., Cohen, S., and Pilowsky, M. 1997. Comparison of resistance level to tomato yellow leaf curl virus among commercial cultivars and breeding lines. Plant Dis. 81:1425-1428.

13. Michelson, I., Zamir, D., and Czosnek, H. 1994. Accumulation and translocation of tomato yellow leaf curl virus (TYLCV) in a Lycopersicon esculentum breeding line containing the L. chilense TYLCV tolerance gene Ty-1. Phytopathology. 84:928-933.

14. Navot, N., Ber, R., and Czosnek, H. 1989. Rapid detection of tomato yellow leaf curl virus in squashes of plants and insect vectors. Phytopathology 79:562-568.

15. Navot, N., Pichersky, E., Zeidan, M., Zamir, D., and Czosnek, H. 1991. Tomato yellow leaf curl virus: A whitefly-transmitted geminivirus with a single genomic molecule. Virology 185:151-161.

16. Navot, N., Zeidan, M., Pichersky, E., Zamir, D., and Czosnek, H. 1992. Use of the polymerase chain reaction to amplify tomato yellow leaf curl virus DNA from infected plants and viruliferous whiteflies. Phytopathology 82:1199-1202.

17. Pico, B., Diez, M. J., and Nuez, F. 1996. Viral diseases causing the greatest economic losses to tomato crop. II. The tomato yellow leaf curl virus-A review. Sci. Hortic. (Amst.) 67:151-196.

18. Pilowsky, M., and Cohen, S. 1990. Tolerance to tomato yellow leaf curl virus derived from Lycopersicon peruvianum. Plant Dis. 74:248-250.

19. Rom, M., Antignus, Y., Gidoni, D., Pilowsky, M., and Cohen, S. 1993. Accumulation of tomato yellow leaf curl virus DNA in tolerant and susceptible tomato lines. Plant Dis. 77:253-257.

20. Vidavsky, F., Leviatov, S., Milo, J., Rabinowitch, H. D., Kedar, N., and Czosnek, H. Behavior of tolerant tomato breeding lines (Lycopersicon esculentum) originated from three different sources (L. peruvianum, $L$. pimpinellifolium and $L$. chilense) upon early controlled inoculation by tomato yellow leaf curl virus. Plant Breed. In press.

21. Zakay, Y., Navot, N., Zeidan, M., Kedar, N., Rabinowitch, H., Czosnek, H., and Zamir, D. 1991. Screening Lycopersicon accessions for resistance to tomato yellow leaf curl virus: Presence of viral DNA and symptom development. Plant Dis. 75:279-281.

22. Zamir, D., Michelson, I., Zakay, Y., Navot, N., Zeidan, N., Sarfatti, M. Eshed, Y., Harel, E., Pleban, T., van-Oss, H., Kedar, N., Rabinowitch, H. D., and Czosnek, H. 1994. Mapping and introgression of a tomato yellow leaf curl virus tolerance gene, Ty-1. Theor. Appl. Genet. 88:141-146. 